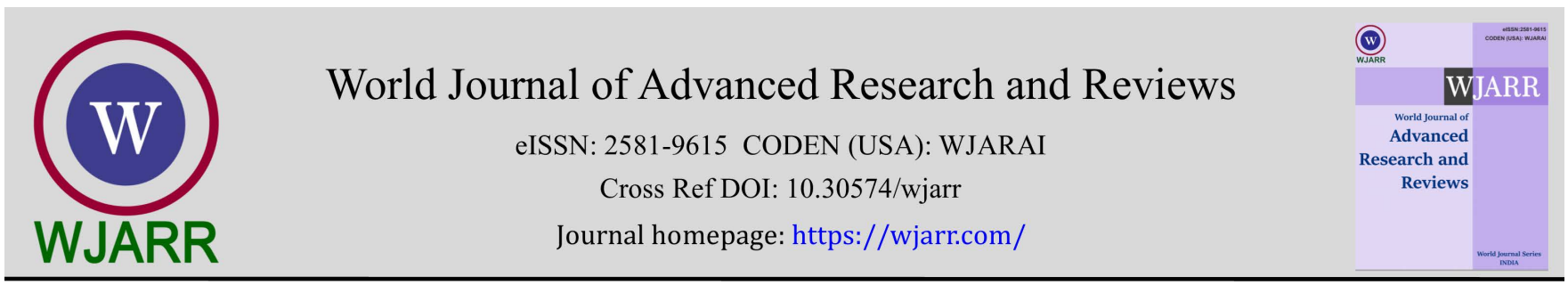

(RESEARCH ARTICLE)

\title{
Corruption in recruitment/Iraq
}

\author{
Daban Sabir* \\ Anti-corruption Expert/Transparency International/Knowledge HubErbil, Iraq.
}

World Journal of Advanced Research and Reviews, 2022, 13(01), 804-810

Publication history: Received on 18 December 2021; revised on 22 January 2022; accepted on 24 January 2022

Article DOI: https://doi.org/10.30574/wjarr.2022.13.1.0076

\begin{abstract}
Corruption in recruitment refers to hiring relatives or close friends, regardless of their merits and abilities. It is a permanent risk for the development of the organization, society and individuals itself. The aim of this study is to investigate some aspects of corrupt hiring in Iraq, as well as the forms of corrupt hiring in all public and non-public sectors. Based on the findings, the result of the research shows that in Iraq, not only the recruitment in public and private sectors are implicated with corruption, but even attaining jobs at UN department and NGOs are deeply characterized by corruption and preferential treatment.
\end{abstract}

Keywords: corruption; recruitment; Iraq; public sector; private sector; non-public

\section{Introduction}

How important is your job in your life? Your job is the structure and the condition of your life; it can affect and shape almost every aspect of your life, starting from your personality, mentality or even physical health. For many of us, having work is survival from a crucial economic environment, particularly if you are living in a country in which government does not support common social programmes, public health and unemployment relief. Currently, the majority of people are only able to afford living costs, accommodation and health insurance through salaries and pensions.

There are many ways to explain the importance of having a job in your current and future life; likewise, it is also important to uphold the recruitment process, clean, correct and fair. A process considers the efficiency of employer's institutions, as well as it respects and values the efforts made by job seekers. Among other things, a greater attempt is required from employers to highlight the sensitivity of this issue and take the necessary steps to avoid corruption and unfair recruitment.

Along these lines, this study illustrates some of the major consequences of corrupt recruitment, where this can be found and the ways corruption reveals itself during employment. In this paper, Iraq is utilized as a core of the analysis. We discuss unfair recruitment at all the sectors, public and private, and also extend such analysis by examining the process of recruitment in UN departments and both national and international NGOs that operate in Iraq currently.

\section{Review of Literature}

Fair recruitment requires full transparency and integrity for the selection of the most qualified candidate among competitors. The entire operation of recruitment should be completely systematic, based on a correct standard and void from emotion and favoritism. Fair and adequate selection and promotion procedures should be in place and respected. Only merit, qualification and efficiency must govern all decisions relating to human resources.

\footnotetext{
${ }^{*}$ Corresponding author: Daban Sabir

Anti-corruption Expert/Transparency International/Knowledge HubErbil, Iraq.

Copyright (C) 2022 Author(s) retain the copyright of this article. This article is published under the terms of the Creative Commons Attribution Liscense 4.0.
} 
In this regard, Iraq demonstrates a great vulnerability, mainly within hiring of civil servants. Nepotism and favouritism are widespread in Iraq and take place at many levels, such as by favouring geographic areas, political affiliation and family or friends. Transparency international (TI) suggests that clientelism and nepotism are often reported to be common practices within Iraqi governmental institutions, which has been leading to massive hiring of unqualified employees by the public sector based on sectarian, political, tribal and family ties [1 p3].

Apart from corrupt recruitment in the public sector, this type of corruption also exists in Iraqi private sectors and even international entities and enterprises. The Iraqi government retains weak safeguards and instructions regarding integrity in the private sector. Due to weak judicial ruling and gaps within governmental controls, private-owned companies in Iraq have gained enough freedom to establish stretchable policies and standards to regulate their recruitment procedure.

The Organisation for Economic Co-operation and Development (OECD) recommends countries to secure clean, efficient and competitive companies in order to have healthier market and greater investment [2]. In other words, clean and free-corrupt companies can help national economy grow, which eventually lead to more employment opportunity and promotion of vacancies.

However, data from Iraq shows faint percentage of labour force participation and unsatisfactory condition by its citizens. World Bank claims that the Iraqi labour force's participation of total population is mired at $42 \%$ in which still fragile and very low. On the other hand, the series of demonstrations in Iraq during 2018 and 2019, illustrates that thousands of university graduates were protesting and demanding jobs from government [3]. Moreover, Thousands of migrants recently from Kurdistan region of Iraq (KRI) have tried to gain entry to European Union nations from Belarus. The migrants are hoping to find a better life abroad, due to lack of employment in the region [4].

\section{Methodology}

The methodology of this research article is in-depth investigation and exploratory analysis of a group of events concerning recruitment. For this purpose, this paper uses recruitment in Iraq as a case study to illustrate some of the major problems of corruption in the hiring process, via various data, statistics and news from a number of sources such as, newspaper articles, government policies, statistics and surveys by international and non-governmental organizations. Items in other media sources are also subject to this study.

\section{Corruption nature in Iraq}

The nature of corruption in Iraq is extreme and perhaps lethal. For example, in June 2014, ISIS's fighters passed the Iraqi border, taking control of approximately one third of the country, including Mosul, the second largest city in Iraq [5]. By the moment ISIS reached Mosul, Iraq's army existed only on paper (ghost solders) [6 p147]. One of the 2,500troop solders turned out to only be 500 men, many of them underfed and with salaries skimmed off by their commanders, allowing commanders to pocket their pay [6 p148].

Due to corruption, Iraqi public institutions operate insufficiently and lack both power and support to stand against corruption. A report in July 2016, by The Risk \& Compliance Portal, alleges that judicial institution and courts in Iraq are paralyzed by political corruption and political interference [7]. The report added, corruption also influenced authorities' willingness to respect court orders and court has announced that it was investigating several corruption cases involving high-ranking officials, yet no court decisions were made public.

As a result of corruption, grievances and demonstrations continue to grow within Iraqi streets, demanding basic public service and employment. During October 2019, a chain of demonstrations took place in Baghdad by thousands of Iraqis, claiming their rights and political integrity [8]. In addition, increasing jobs and employment opportunities was another major concern of protesters and they called for a radical transformation within government and politics to enhance accountability and reduce corruption [9 p14].

Overall, Iraq is considered to be one of the most corrupt countries worldwide. The capacity of the country has been almost completely taken by corruption. The CorruptionPerceptions Index (CPI)( CPI is the statistics in which every year is launched by TI. It includes more than 170 countries and was first started in 1995. In the CPI survey the more higher the ranking number of a country, the more corrupt the country. For example, A-country ranked 20th out of 170, and Bcountry ranked 25th out of 170. This means B-country is more corrupt than A-country; Our Organisation - Mission, Vision and Values. (n.d.). Retrieved from TI website: http://www.transparency.org/whoweare/.) ranks Iraq among most corrupt countries in the globe. For instant, the ultimate data of 2019 from CPI put Iraq at 162 grades out of 198 
countries. In addition, CPI in 2014 ranked Iraq 170 out of 175 countries and in 2015, the country was ranked 161 out of 168 countries. It shows that only Iraq, Libya and Sudan are ranked at the bottom ten countries from the Middle East and North Africa region, far beyond countries such as Germany and Norway that ranked at the lowest which are considered to have the lowest levels of corruption. The 2014 CPI also scored Iraq just 16 on a scale where 0 indicates that a country is perceived to be highly corrupt and 100 is where a country is perceived to be very clean. Only Afghanistan, North Korea, South Sudan, Somalia and Sudan scored worse.

\section{Labour Force in Iraq}

Iraq is currently confronting jobs crises and it has one of the lowest employment-to-total population ratios in the region. According to International Labour Organization, labour force participation is mired at 49\% for federally-administered Iraq and $40 \%$ for the KRI [10]. Iraqi University graduates, continuously, have been demonstrating outside government ministries in Baghdad, asking for jobs, good quality of life, and no favouritism [11].

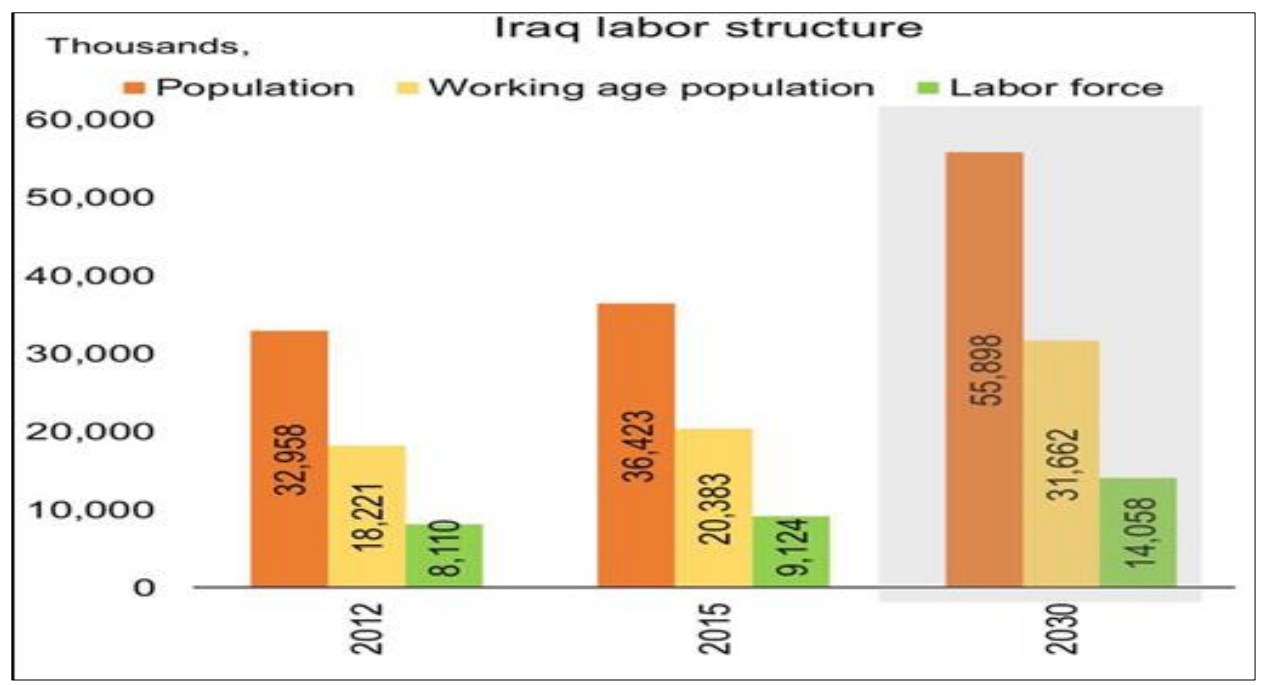

Figure 1 between 2015 and 2030, the demand for job will burgeon as the labor force grows by 54\%

In addition, a report claims that in 2016 Iraq experienced a 2.5 million vacancy shortage and this number is estimated to be doubled by 2030. The report illustrates some facts that have influence on pushing up the demand for jobs, just as growth in Iraqi adult population, migration of large numbers of poor communities from rural area to urban areas, attempting recruitment, private sector, due to corruption and lack of business integrity [12 p2-4].

Iraq is one of the world's top five oil producers, yet its people rarely benefit from the country's energy riches, suffering from poor public service, poverty and unemployment. Both public and private sectors in Iraq hold inefficient policy in creating new jobs. According to a report by World Bank, from 2007 until 2012, 40\% of the Iraqi labour force is contributed by public administrations, while private sector contributes $60 \%$ of the jobs [13 p127]. For these five years, private sectors in Iraq did not play a significant part in generating vacancy. Nearly all the recruitments were adopted by government.

In order for Iraq to catch up with the satisfaction of its people for employment and more job opportunities, it needs to improve accountability in government sector and integrity for private sector. Iraqi government suffers from two major problems: overstaffing and inefficiency. The recruitment of civil servants is not based on merit; rather, it is based on political affiliation, nepotism and favouritism. On the other hand, private sector in Iraq is not guided by efficient ethics and anti-corruption policies. Without vacancy announcements, employees are directly hired by companies, depending on their relationships and connections with heads of the companies and decision makers.

\section{Corruption in Recruitment-Iraq}

Recruitment in Iraq is more often engaged in corruption and lacks some legitimate standards such as vacancy announcements, transparent recruitment processes, independent interview panels and merit based selection of the applicants. Moreover, in the matter of recruitment, nepotism and favouritism are the two most concerning forms of corruption in Iraq. Senior manager and decision makers abuse their power in favour of helping their relatives, friends, tribes and political parties at the expense of others. 
This section essentially focuses on some of the major problems and unjust issue, occurring during recruitment in Iraq. It sheds light on corruption at three main source of employment: recruitment in public sector, recruitment in private sector and recruitment in international corporations and NGOs.

\subsection{Recruitment in Public Sector}

Governmental positions and vacancies are hardly ever advertised or follow a correct procedure. Instead of selection for the best match between experience and skills of applicants and the objective requirements for the position, recruitment at both Iraqi central government and KRG is based on applicant influence and connection. Government vacancies are available upon applicant request when someone with influence needs a job. According to a 2011 study by the UN on Corruption and Integrity Challenge in the Public Sector of Iraq, just over a third of all civil servants in Iraq obtained jobs through friends and relatives. Meanwhile, about a quarter learned of a job opportunity through the centralized appointment system for graduates and 13.7 per cent through public advertisements.

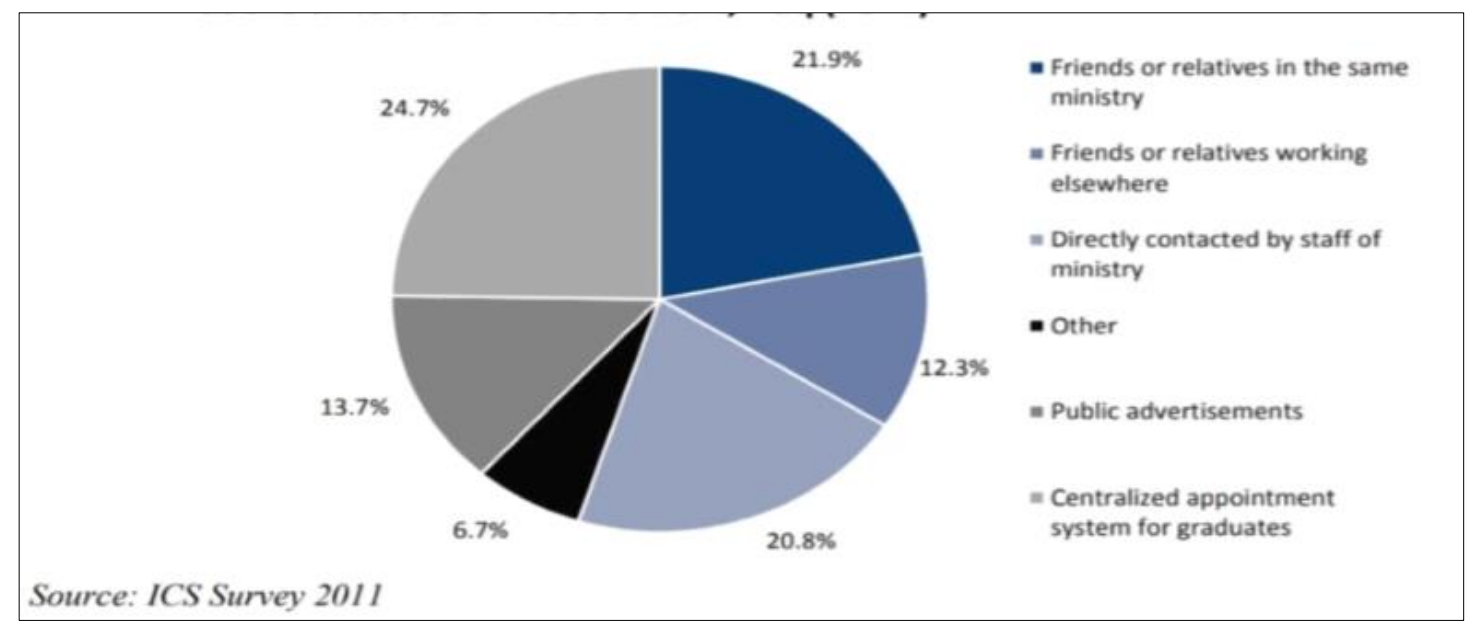

Figure 2 Percentage distribution of civil servants, by source of information about job vacancy at the time of their recruitment, Iraq (2011)

Both Iraqi central government and KRG are struggling now to pay salaries, due to extensive recruitment of civil servant in public sector. Currently, the number of civil servant in Iraq is massive and exceeds reasoning. People are recruited upon their political agenda, influence, connections and family ties, rather than government policy and requirements. At the present time, KRG has about 1.5 million employees in the government sector and this number is nearly quarter of the total population of Iraqi Kurdistan [14 p63].

Overall, the performance of civil servants in Iraq is very weak and inefficient for the following reasons. First, there is no job description; second, civil servants are equipped with very little of training and capacity building; third, recruitment and promotion in public sector are not based on merit competition; and forth, the greater influence and communication with political parties has, the greater position and responsibilities is gained. Last but not least, there is a weak rule of law for those who engaged in corruption cases and abuse of public entrusted power. There is no punishment for the perpetrators of crimes of corruption, because at both Kurdistan region and central Iraq, the Iraqi judicial system is not free from political interventions. If a senior civil servant is caught on a case of corruption, the only punishment he gets is to be dismissed from his duty.

\subsection{Recruitment in Private Sector and International Corporations}

Private sector is the engine and building blocks of national economy growth. Clean business characters drive prosperity and more employment opportunity. The Organisation for Economic Co-operation and Development (OECD) states,

"Clean, efficient and competitive companies help to ensure healthier markets and greater investor confidence. Governments can promote greater integrity in the business sector by encouraging companies to adopt stronger internal controls, ethics and anti-corruption compliance." [2].

Private sector in Iraq dominates about 60\% percent of the jobs; however, Iraqi authorities have displayed very small effort to lay out anti-corruption obligations and promote integrity in business [16] The major drawbacks are absence 
of legislation addressing bribery in the private sector or of foreign officials, trading of influence, as well as insufficient protection of witnesses and whistleblowers [1 p6].

Moreover, the term of "Free Market" has been grasped inaccurately by majority of people and abused by authorities in Iraq. Market in Iraq is excessively free with very few government restriction or involvement. It is the role of government to interference market and restricts illicit activity in business, in order to avoid monopoly and protect fair competition.

In the absence of such role of government in market, the hiring process in private and local companies in Iraq usually is governed by a highest-ranking person in the company or chief executive (CEO). The process lacks vacancy announcement, autonomous interview panel and merit selection for the most qualified candidate. In KRI recently a few human resource companies emerged to work as a third independent party during recruitment such as, MSelect, Erbil Manpower Company Ltd., as well as Shull for employment services. However, without government restrictions and regulations, the majority positions in private sector are filled unsystematically and without standards.

On the other hand, the hiring process in international corporations operating in Iraq is not free from nepotism and favoritism, though the process is at a higher standard and more acceptable. In some ways, international corporations are guided by certain guidelines and procedures for recruitment from their headquarters. At present day, more than 40 international oil companies are operating in entire Iraq and they hire thousands of national employees each year [16]. However, during 2018, protests erupted in southern Iraq and Basra, complaining against employment in international oil companies. The Protesters accused the oil companies for hiring foreign workers beyond the limits, as well as employing political party members and relatives [17 p8].

\subsection{Recruitment in NGOs and UN departments.}

Non-governmental originations and UN departments possibly dominate half of the announced vacancies in Iraq, particularly during the last five years. After the fall of city Mosul in June 2014 by extremist ISIS, the number of humanitarian organizations has significantly increased in Iraq. Currently, there are about 70 national NGOs in addition to over a hundred international NGOs operating in Iraq, providing different types of humanitarian assistance and protecting human rights as well [18]. For example, in 2015 more than 2000 vacancies were published only on NCCI's(The NGO Coordination Committee for Iraq (NCCI) is a member-led organization established in 2003 to coordinate principled, collective NGO action in order to foster development, address humanitarian needs, and promote respect for human rights in Iraq) website. Besides, UN has 21 agencies, funds and programmes including 16 resident and four non-resident agencies and they implement over 700 projects all over the 18 governorates of Iraq [19]. UN departments in Iraq and KRI post several vacancies on their websites almost every working day [20].

The exercise of recruitment in both NGOs and UN departments goes along with some standard procedures, along with individualized procedures, including fundamental standards such as including vacancy announcement, selecting qualified competitors and interview stage. In spite of the standards, recruitment at NGOs and UN in Iraq, is still is a matter of concern and corruption suspension. The following paragraphs illustrate some of the major dishonest dealings in UN and NGO in further details.

\subsubsection{Corruption in UN's Recruitment.}

Nepotism continues to be important factors in securing employment in Iraq. Hiring new staff relies on one's connections or influence rather than merit. It is very common for the applicant to establish connection and Wasta (Wasta is an Arabic word that loosely translates into nepotism. It refers to using one's connections and/or influence to get things done through favouritism rather merit), after submitting their CVs to employers.

The same scenario is taking place at UN office in Iraq. Statements of dissatisfaction and words of gossip are heard among skilled young people who desperately seeking jobs at the UN offices in Iraq. If you work among UN employees in Iraq, you are fully aware about the personal relationships and family ties between them, such as husband and wife, siblings, cousins and friends. HR departments have been known to make use of manipulative hiring practices to bring in their friends, relatives, etc.

United Nations in Iraq is the vocal critics of the political elite and corruption. United Nation Convention Against Corruption (UNCAC) request the state parties to adopt accountability in the management, transparency and recruitment based on merit [21 art,7]. Yet, anyone who has spent any time interacting with the UN community, will sense the corruption, especially the corrupt hiring practices that exist within the United Nations agencies. It is common practice for the UN to post job vacancies online in order to comply just with standard regulations, even though some of these positions have already been assigned for someone with connection. The majority of the announced positions require 
written tests; regardless of the efforts, time and the energy that competitors spend, someone else has already arranged the position for him/herself.

\subsubsection{Corruption in NGO's Recruitment}

The number of NGOs, especially humanitarian, has grown rapidly over the last 20 years and now the national and international NGOs combine a great portion of labour force in Iraq. Nevertheless, NGOs in Iraq are no more immune to corruption than private owned companies with reference to recruitment. NGO's staff and members are often reluctant to talk about corruption for fear that it will lead to bad publicity and, consequently, a loss of funding

Recruitment and human resource management are exposed to a very high level of risk of nepotism in NGOs. Recruitment decisions could be influenced by family, tribal, clan or ethnic considerations. Problems of nepotism or wasta can also continue into influencing staff deployment plans or the promotion and supervision of staff.

Corruption is already extensively prevalent in Iraq; it has also been an entry point for national staffs to secure an employment contract in humanitarian aids. Corruption practices during recruitment process are usually initiated by job seekers, in which they try to establish connection and wasta with someone inside the organisation to provide them with leniency or coaching on how to orient their CVs in accordance with the job requirements. Relying on relatives and friends is well notable for applicants, undermining the standards of merit recruitment.

The public in Iraq are well-acquainted with nepotism in employment at NGOs, particularly in the sector of humanitarian aids. According to a survey by Humanitarian Policy Group (HPG) in 2019, the majority of respondents in Mosul (a city in northern Iraq) reported that the lucrative jobs in NGOs are dependent upon wasta or who you know. Skilled jobseekers nowadays have little hope of finding work; they believe personal connections and wasta are more important than qualifications to succeed.

Another major problem emitting from humanitarian organisations is the selection of internal candidates. External candidates spent effort, time and energy on their applications and interviews or sometime tests as well; meanwhile the position has already given to an internal candidate. Some of these positions are announced only to fulfill the organizations' recruitment policy and some others are relevant to the promotion of the positions in fact, not actual vacancies. The latter can also be described as "pretended vacancies". It is preferred to promote the internal candidates directly, without taking footsteps of fake recruitment process and wasting time and energy of external candidates.

\section{Conclusion}

Corruption in Iraq, particularly in the form of nepotism and favouritism, undermines the selection of the most qualified person and the standards of merit-competition. It can also be one of the major reasons behind operational defect of the system of governance in Iraq. Both public and private sectors lack recruitment standards and monitoring procedures to uphold the recruitment process clean and correct.

Additionally, the hiring practices in the private sector are considered to be unfair and are not transparent about the position. Iraqi regulations and laws do not provide any rules on the process of recruitment in private sectors and companies. This absence of rule of laws raises a question for future investigation in legislation.

Last but not least, recruitment in UN departments and NGOs forms a great portion of employments nowadays. It is not free from corruption and nepotism, yet very few of people, reveal thoughts and opinions about it. UN and NGOs are supposed to be the protector of human rights; however, sometimes even these institutions are contradicted with corruption and human rights violations. UN departments and NGOs in Iraq are being subject to vast amount of critics and complaints by newly graduates and skilled jobseekers.

\section{References}

[1] Maxime AG. Iraq: overview of corruption and anti-corruption. U4 web-based resource centre: Transparency International. 2013; 9: 374.

[2] EU: OECD. Business integrity [Internet].

[3] Charles S. Iraq protests: Thousands of graduates demand jobs from government [Internet]. Al-Jazeera. 2019.

[4] Khazan J. Kurdistan's unemployed youth pull up stakes, move to Europe [Internet]. Rudaw. 2021. 
[5] Syria's war explained from the beginning [Internet]. Al-Jazeera. 2018.

[6] Daban S. The humanitarian crisis in Iraq is the cost of corruption. International Journal of Scientific and Research Publications. September 2017; 9: 143.

[7] GAN Integrity. Iraq corruption report [Internet].

[8] ReliefWeb [Internet]. Genève: Euro-Med Monitor; 2019 Dec 22. Iraqi protests: An audacity to kill and absent justice. 22 Dec 2019.

[9] Neither the European Asylum Support Office (EASO. Iraq: The protest movement and treatment of protesters and activists. EU: Publication Office of the European Union. 2020.

[10] Labour Organization International. Promoting decent work in Iraq [Internet].

[11] Zana G. Iraq protests one year on: Demands, Iran's role, al-Kadhimi and the future [Internet] Alarabya News. 2020.

[12] Jobs in Iraq: a primer on job creation in the short term [Internet]. World Bank. 2018.

[13] World Bank. The growth-employment nexus [Internet].

[14] Kawa J. Corruption as a major challenge in newly developing Kurdistan [research paper] Canada: Simon Fraser University. 2014.

[15] The Information Analysis Unit. Iraq Labour Force Analysis 2003-2008 [Internet] Reliefweb. Jan 2009.

[16] Iraq Business News. List of International Oil Companies in Iraqi Kurdistan [Internet]

[17] James MA, Zmkan AL. The politics of unemployment in basra: Spotlight on the oil sector. Iraq, Sulaimani: Institute of Regional and International Studies (IRIS). 2019.

[18] NCCI Website. Partners [Internet]

[19] UN Website. Where we work: The UN's key activities in Iraq [Internet]

[20] Vacancies with UN and other international organizations [Internet] unjobs website.

[21] UN Office on Drugs and Crime. United Nations convention against corruption. Patent 2349 UNT. 2005 Dec 14. 